\title{
THE RELATIONSHIP BETWEEN FEMALE SIZE AND EGG SIZE IN THE FRESHWATER CRAYFISH AUSTROPOTAMOBIUS TORRENTIUM
}

\author{
I. MAGUIRE, G.I.V. KLOBUČAR, R. ERBEN
}

\begin{abstract}
Department of Zoology, Faculty of Science, University of Zagreb, Rooseveltov trg 6, 10000 Zagreb, Croatia.

E-Mail: imaguire@public.srce.hr
\end{abstract}

Reçu le 20 décembre 2004

Accepté le 21 juin 2005

Received December 20, 2004

Accepted June 21, 2005

\begin{abstract}
The aim of our research was to gather information about the reproduction cycle of Austopotamobius torrentium in Croatia. The research was conducted between October 1998 and April 2000 in streams on the Medvednica Mountain (north-west Croatia). We caught 767 females, of which 92 (11.99\%) were berried. Berried females were captured from the beginning of November until mid June of the following year. Total length (from the tip of the rostrum to the end of telson) of the smallest female with pleopodal eggs was $5.40 \mathrm{~cm}$, while the longest was $8.70 \mathrm{~cm}$. Diameter of pleopodal eggs varied from $0.24 \mathrm{~cm}$ to $0.34 \mathrm{~cm}$ (mean $\pm \mathrm{SD}=0.28 \pm 0.02$ ) and their number per female from 1 to 104 . Correlations between female size (total length and weight), number of pleopodal eggs and egg diameter were done. We found positive correlation between female length and number of eggs $(r=0.46)$ and between female length and egg diameter $(r=0.29)$, as well as between female weight and egg number $(r=0.50)$ and female weight and egg diameter $(r=0.30)$. Weak positive correlation was recorded between number of eggs and their diameter $(r=0.06)$.
\end{abstract}

Key-words: stone crayfish, Austropotamobius torrentium, fecundity, egg size.

\section{RELATION ENTRE LA TAILLE DES FEMELLES ET LEURS @EUFS CHEZ L'ÉCREVISSE AUSTROPOTAMOBIUS TORRENTIUM}

\section{RÉSUMÉ}

Le but de notre recherche a été de rassembler les informations sur le cycle reproductif d'Austropotamobius torrentium. La recherche a été menée entre octobre 1998 et avril 2000 dans les ruisseaux de la montagne Medvednica. Nous avons capturé 767 femelles, dont $92(11,99 \%)$ avec les œufs pléopodaux. Les femelles avec les œufs pléopodaux ont été trouvées à partir du mois de novembre jusqu'à la mi-juin. La longueur totale de la plus petite femelle avec les œufs pléopodaux a été $5,40 \mathrm{~cm}$ et la plus longue $8,70 \mathrm{~cm}$. La taille des œufs pléopodaux a varié entre $0,24 \mathrm{~cm}$ et $0,34 \mathrm{~cm}$ (moyen $\pm \mathrm{SD}=0,28 \pm 0,02)$ et le nombre d'œufs par femelle entre 1 et 104. Les corrélations entre la taille des femelles (la longueur et le poids), le nombre d'œufs et leur taille ont été calculées. Nous avons trouvé une corrélation positive entre la longueur des femelles et le nombre d'œufs $(r=0,46)$, entre la longueur des femelles et la taille des œufs $(r=0,29)$, entre le poids des femelles et le nombre d'œufs $(r=0,50)$ et le poids des femelles et la taille des œufs $(r=0,30)$. Une corrélation faible a été notée entre le nombre d'œufs et leur taille $(r=0,06)$.

Mots-clés : écrevisse des torrents, Austropotamobius torrentium, fécondité, taille des œufs. 


\section{INTRODUCTION}

The stone crayfish (Austropotamobius torrentium (Schrank, 1803)) is one of four native European crayfish species inhabiting Croatian freshwater habitats and is protected by the Croatian law - Law of Nature Conservation (NARODNE NOVINE 30/94) and Rule Book on Protection of Crayfish (Crustacea, Astacidae) (NARODNE NOVINE 76/98). It is naturally distributed in the continental part of Croatia, in the Drava-Danube and Sava River basins (MAGUIRE 2002; MAGUIRE and GOTTSTEIN-MATOČEC 2004). Our latest field research (autumn 2004) confirmed its occurrence in the Adriatic Sea basin (the channel Badnjevice close to the town of Imotski), where its presence is of anthropogenic origin.

Territory of $A$. torrentium in Europe extends from $50^{\circ} \mathrm{N}$ in Germany to $41^{\circ} \mathrm{N}$ in Macedonia and $8^{\circ} \mathrm{E}$ on the Rhine to about $24^{\circ} \mathrm{E}$ in Romania (LAURENT, 1998). According to MACHINO, SKET and TRONTELJ (2004) it is distributed even further south as far as Greece.

As this species is the smallest in the family Astacidae and little is known about its ecology, biology and life cycle, the aim of our research was to gather information about its reproductive cycle. In crayfish reproduction, one of the main factors affecting fecundity is egg size. It is known that an increase in egg size causes decrease in fecundity (RHODES and HOLDICH, 1982; BREWIS and BOWLER, 1985; CARRAL et al., 1994; CARRAL et al., 2004), but it is not known what is the relation between female size and egg size. Therefore, in this research we dealt with this question.

\section{MATERIAL AND METHODS}

The research was conducted from October 1998 until April 2000. Crayfish were trapped twice a month, in three streams $\left(45^{\circ} 51^{\prime} \mathrm{N}, 1^{\circ} 58^{\prime} \mathrm{E}\right.$; $45^{\circ} 52^{\prime} \mathrm{N}, 1^{\circ} 59^{\prime} \mathrm{E}$; $45^{\circ} 56^{\prime} \mathrm{N}$, $15^{\circ} 54^{\prime} \mathrm{E}$, respectively) on the Medvednica Mountain. We used baited hand-made traps (usually 25 per locality) that were set along both banks of the stream (in $10 \mathrm{~m}$ intervals) and were left there over night. For each trapped female we recorded the weight (using a Pesola balance) and the total length (using Vernier calliper) as well as their reproductive status (state of glair glands, colour of internal eggs and number and diameter of external eggs). After examination, crayfish were released back into the water. For statistical analyses (descriptive statistic; Pearson correlation; regression equitation) we used Microsoft Excel and Statistica 5.0 programs.

\section{RESULTS AND DISCUSSION}

A total of 767 Austropotamobius torrentium females were caught, from which 262 (34.16\%) were with activated glair glands and 92 (11.99\%) were berried. Occurrence of cement glands clearly defines sexually mature females (GRANDJEAN et al., 1997a, 1997b). According to our research it seemed that females in Croatian populations reached sexual maturity from a total length of $5.40 \mathrm{~cm}$ (Table II), while in Austria females were mature at a total length of $5.90-6.50 \mathrm{~cm}$ (STREISSL and HÖDL, 2002), and in Switzerland size of females at maturity is $2.50 \mathrm{~cm}$ carapace length, (ranged from 2.36-3.00 cm) (STUCKI, 2002). In Astacus astacus, development of glair glands depends on the female's nutritional status (ACKEFORS, 1999) and we suppose that $A$. torrentium follows the same pattern. As in the studied Croatian populations females developed glair glands at smaller size, we could suppose that this is either because conditions in streams favour faster attainment of optimal nutritional status, or because populations were regenerating and growing, so sexual maturity was reached earlier and at smaller size, as to compensate for population fluctuations or some forms of environmental stress (MOMOT, GOWING and JONES, 1978; MOMOT, 1993; KULESH, ALEKNOVICH and ABLOV, 1999; REYNOLDS, 2002). 
Difference in the number of females caught with active glair glands and the ones with external eggs could be explained by the fact that during egg-bearing period females are less active. Therefore their catchability is lower and recorded percentages under represent the actual numbers present. The ovigorous females carried eggs from early November until mid-June the following year (Table I). Hatching in local populations occurred a month earlier than in Germany (TROSCHEL, SCHULZ and BERG, 1995) and a few weeks earlier than in Austria (STREISSL and HÖDL, 2002). The probable cause of this finding is different geographical latitude of investigated populations in three countries.

Freshwater crayfish, especially astacids, have low fecundity, with values usually fewer than 250 eggs (BROWN and BOWLER, 1977; MOMOT, 1991; CARRAL et al., 1994; REYNOLDS, 2002; POLICAR, 2004). Fecundity is generally proportional to female size and number of eggs can differ markedly between different populations of the same species due to environmental conditions (REYNOLDS, 2002; SKURDAL and TAUGBØL, 2002). In Germany females may incubate 40 to 70 eggs (SCHELLENBERG, 1928) while in Switzerland STUCKI (2002) found that the average number of eggs per female was 75 (range 20 to 120) at one sampling site, while at another site it was 48 (range 35 to 65), and their size varied from 0.25 to $0.31 \mathrm{~cm}$. In Croatian populations situation is similar; average number of pleopodal eggs per female was 62.63 (range 30 to104) and their mean size was $0.28 \mathrm{~cm}$ (range 0.24 to $0.34 \mathrm{~cm}$ ) (Table II).

\section{Table I}

Timing of different reproductive functions throughout a year. + was used to show presence of certain function.

\section{Tableau I}

Apparition des fonctions reproductives pendant l'année. + marque la présence de la fonction.

\begin{tabular}{|l|c|c|c|c|c|c|c|c|c|c|c|c|}
\hline Function & \multicolumn{10}{|c|}{ Months } \\
\cline { 2 - 15 } & 1 & 2 & 3 & 4 & 5 & 6 & 7 & 8 & 9 & 10 & 11 & 12 \\
\hline Glair glands & & & & & & & + & + & + & + & & \\
\hline Yellow internal eggs & & & & & & & & + & + & & & \\
\hline Brown internal eggs & & & & & & & & & + & + & & \\
\hline External eggs & + & + & + & + & + & + & & & & & + & + \\
\hline
\end{tabular}

\section{Table II}

Statistical description of measured parameters.

\section{Tableau II}

Description statistique des paramètres mesurés.

\begin{tabular}{|l|c|c|c|c|c|}
\hline & $\mathrm{N}$ & Mean & Minimum & Maximum & $\mathrm{SD}$ \\
\hline Weight / g & 73 & 16.685 & 6 & 25 & 5.125 \\
\hline Length / cm & 68 & 7.319 & 5.4 & 8.7 & 0.802 \\
\hline Egg number & 73 & 62.630 & 30 & 104 & 15.102 \\
\hline Egg dimeter / cm & 71 & 0.278 & 0.240 & 0.340 & 0.020 \\
\hline
\end{tabular}


It has been shown (MANKAMPA and CHAISEMARTIN, 1996) that eggs attached to the pleopodal appendages present a good basis for estimation of potential young production, and that low biotic potential observed within some females is a consequence of poor trophic niche, and abiotic factors (temperature, pH) (ABRAHAMSSON, 1966). Also females lose their eggs during the egg-bearing period due to poor egg attachment, disturbance, fungal infections and aggressive contacts with other crayfish (CARRAL et al., 1994; REYNOLDS, 2002; MAGUIRE et al., 2002, CARRAL et al., 2004). As a result, including females with just a few eggs attached to their pleopodal appendages into the analyses would not yield realistic results. We therefore excluded from analyses females that had a low number of pleopodal eggs. The number of females included in the analyses is given in Table II. Values of correlations between measured parameters are shown in Table III while the relations between females and their eggs are shown on Figures 1a, b, c, and $d$. The existence of positive correlation between female size and total number of eggs they produce is known from the literature (HUNER and LINDQVIST, 1991). Contrary to HARLIOĞLU (1996) and HARLIOĞLU and TÜRGÜLÜ, (2000), and similar to RHODES and HOLDICH (1982), BREWIS and BOWLER (1985), KÖKSAL (1988), TAUGBØL, SKURDAL and FJELD (1988), CARRAL et al. (1994, 2004), STUCKI (1999, 2002), and EVERSOLE et al. (2002), we found positive correlation between female size and number of eggs. Correlation coefficients reported by RHODES and HOLDICH (1982), BREWIS and BOWLER (1985) and CARRAL et al. (1994) showed a great variability (0.39-0.93). CARRAL et al. (2004) explains that probable cause of correlation coefficient variability is related to the different number of animals, the number of populations, number of reproductive season and the phase of embryonic development taken into consideration.

In accordance with our results STUCKI (1999, 2002), and EVERSOLE et al. (2002) found a significant positive correlation between female size and egg diameter. That was not a case in the research on A. astacus made by LAHTI and LINDQVIST (1983) and the one on Austropotamobius pallipes made by CARRAL et al. (2004). However, although variability in egg size of the spawn is high, it is noted that larger females usually have bigger eggs (WOODLOCK and REYNOLDS, 1988).

While CARRAL et al. (2004) found negative and low correlation between A. pallipes egg number and their diameter, we found that for $A$. torrentium this correlation was positive and insignificant. According to CARRAL et al. (2004) correlation between egg number and their diameter is more evident among different species as those with higher fecundity spawn smaller eggs, e.g. A. pallipes carries fewer eggs than Astacus. leptodactylus and Pacifastacus leniusculus, but they are larger (LOWERY, 1988).

\section{Table III}

Correlation values $(r)$ and probability values $(p)$ presented in the table as $r / p$.

* was used for statistically significant correlations.

\section{Tableau III}

Valeurs de la corrélation (r) et valeurs de la probabilité (p).

* corrélations significatives.

\begin{tabular}{|l|l|l|l|l|}
\hline \multicolumn{1}{|c|}{$r / p$} & \multicolumn{1}{|c|}{$\begin{array}{c}\text { Weight } \\
(\mathrm{g})\end{array}$} & \multicolumn{1}{|c|}{$\begin{array}{c}\text { Length } \\
(\mathrm{cm})\end{array}$} & \multicolumn{1}{|c|}{ Egg number } & \multicolumn{1}{|c|}{$\begin{array}{c}\text { Egg diameter } \\
(\mathrm{cm})\end{array}$} \\
\hline Weight $(\mathrm{g})$ & $1.000 /--$ & $0.927 / 0.000^{*}$ & $0.500 / 0.000^{*}$ & $0.298 / 0.014^{*}$ \\
\hline Length $(\mathrm{cm})$ & $0.927 / 0.000^{*}$ & $1.000 /--$ & $0.461 / 0.000^{*}$ & $0.285 / 0.020^{*}$ \\
\hline Egg number & $0.500 / 0.000^{*}$ & $0.461 / 0.000^{*}$ & $1.000 /--$ & $0.056 / 0.655$ \\
\hline Egg diameter $(\mathrm{cm})$ & $0.298 / 0.014^{*}$ & $0.285 / 0.200^{*}$ & $0.056 / 0.655$ & $1.000 /--$ \\
\hline
\end{tabular}


egg number $=-.320+8.608$ * length

Comelation: $r=.46134$

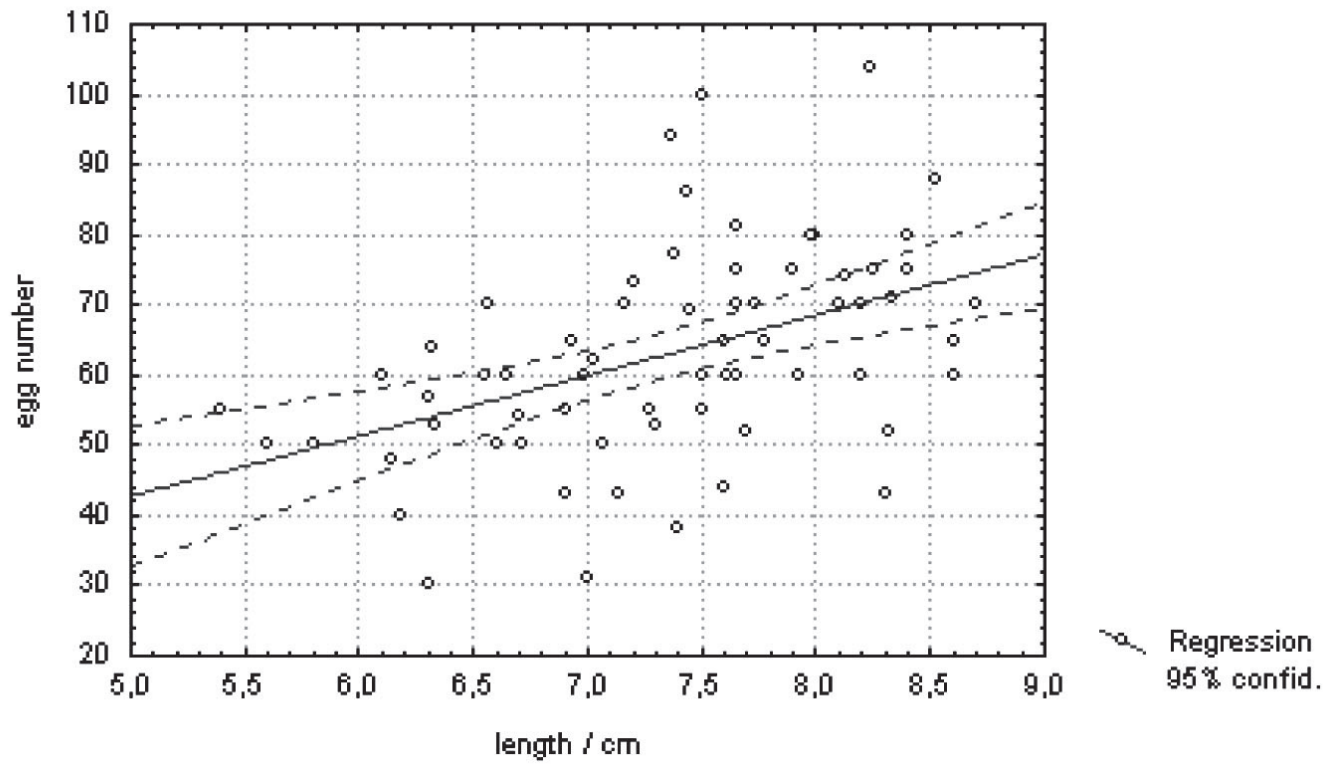

Figure 1a

Relation between females' length and number of pleopodal eggs.

Figure 1a

Relation entre la longueur des femelles et le nombre d'œufs pléopodaux.

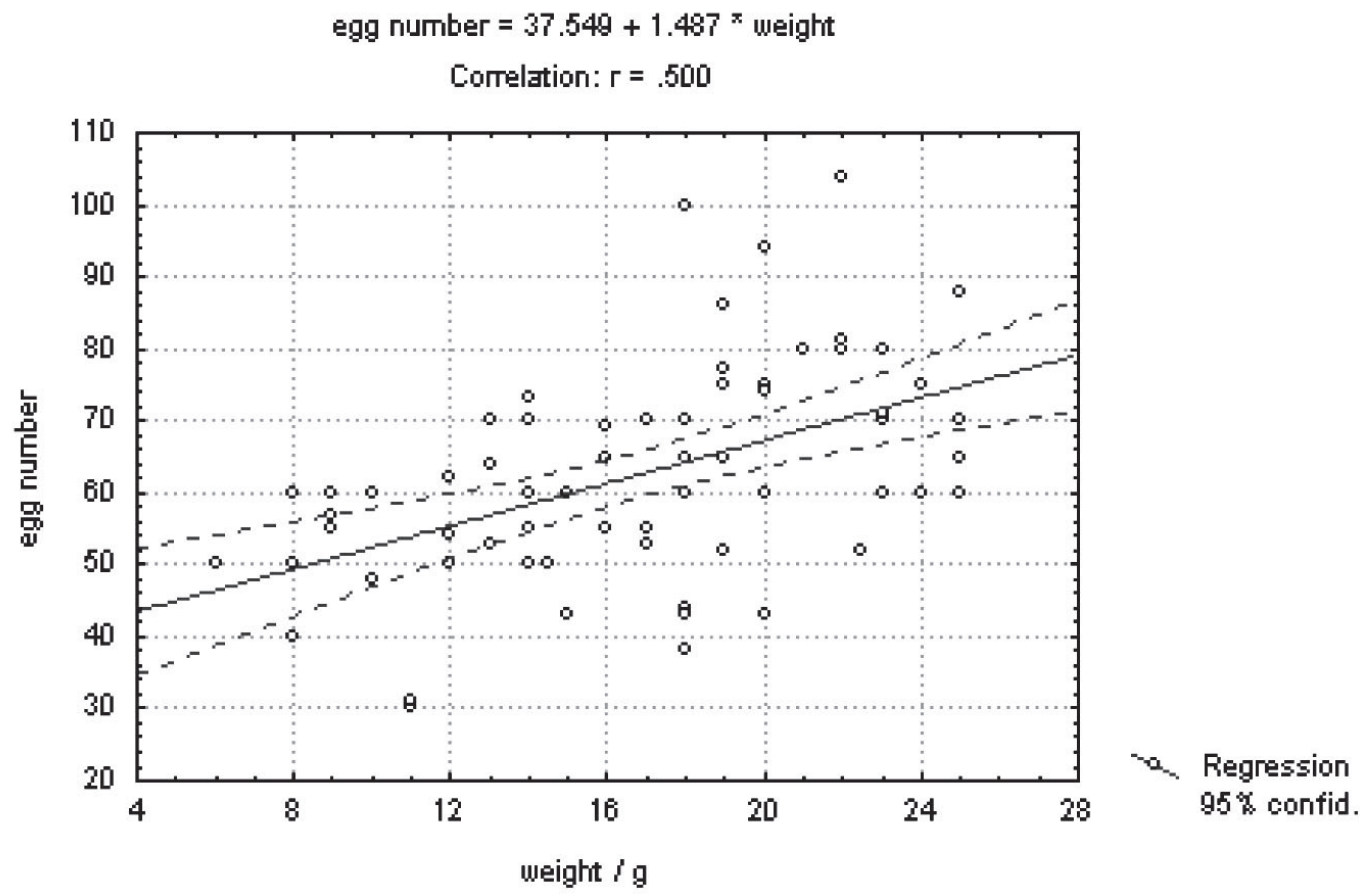

Figure 1b

Relation between females' weight and number of pleopodal eggs.

Figure 1b

Relation entre le poids des femelles et le nombre d'œufs pléopodaux. 
egg diameter $=.226+.007 \times$ length

Comelation: $r=.284$

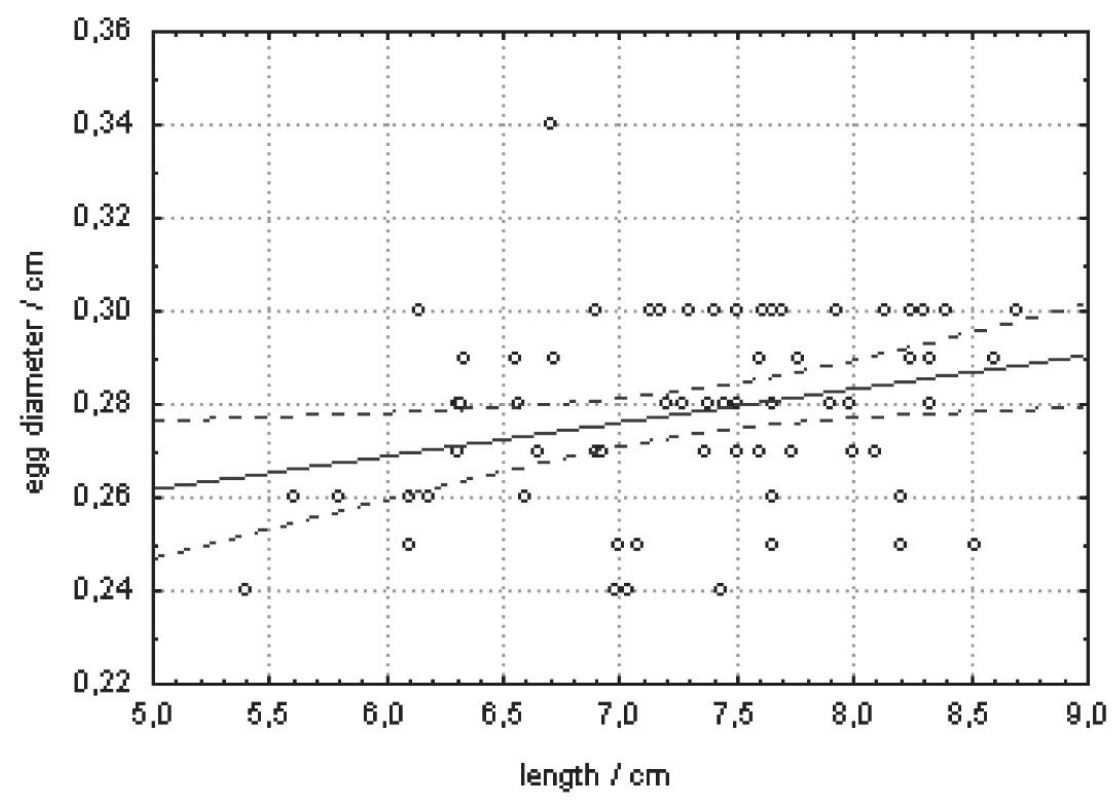

- Regression $95 \%$ confid.

Figure 1c

Relation between females' length and egg diameter.

Figure 1c

Relation entre la taille des femelles et le diamètre des œufs.

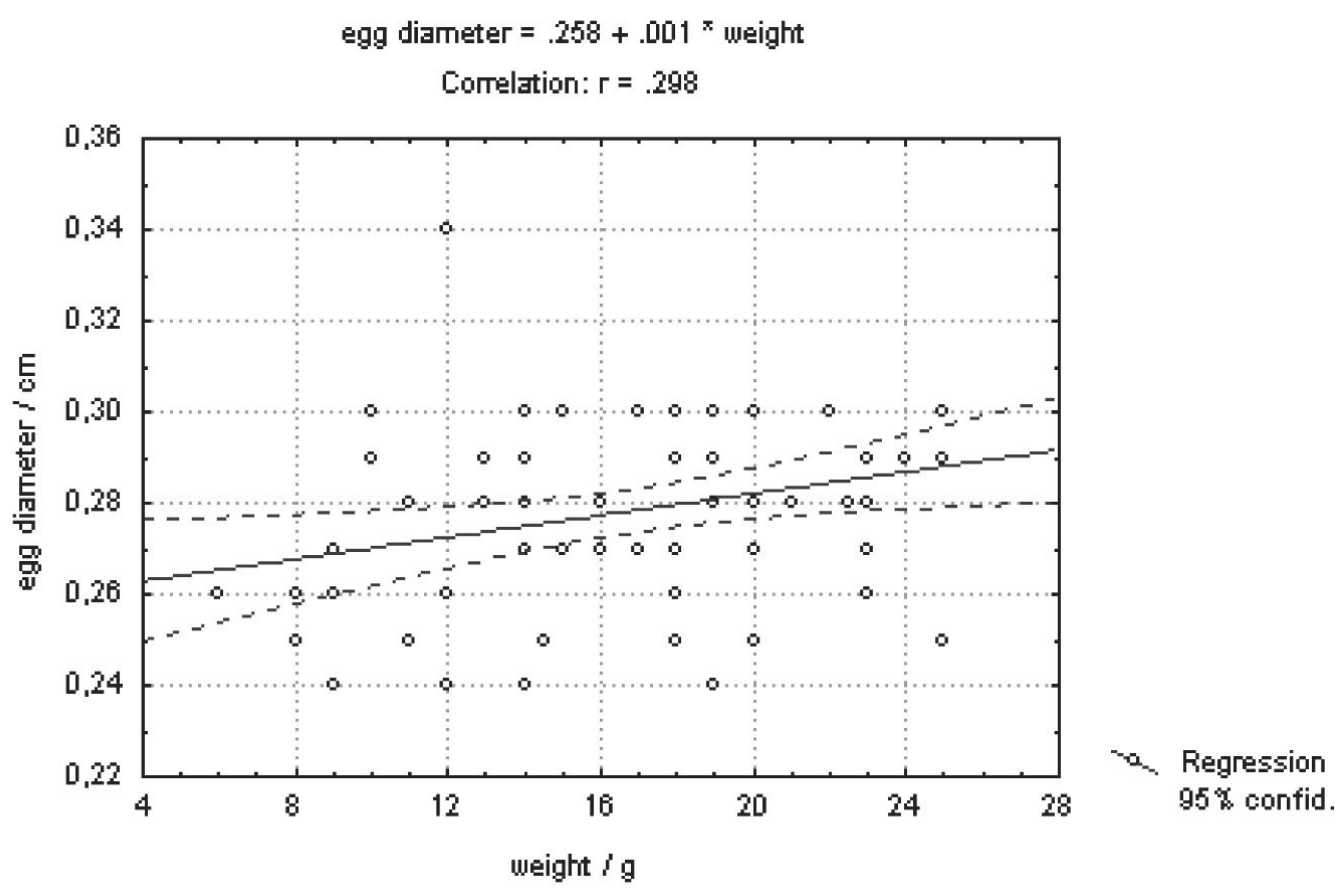

Figure 1d

Relation between females' weight and egg diameter.

Figure 1d

Relation entre le poids des femelles et le diamètre des œufs. 


\section{CONCLUSION}

This research has shown that positive correlation does exist between the females'size and the number of their eggs, so it makes it probable to estimate $A$. torrentium female's pleopodal fecundity on the basis of her size. It is known (MANKAMPA and CHAISEMARTIN, 1996) that eggs attached to the pleopodal appendages present a good basis for estimation of potential young production, but estimation of the year recruitment in the population also depend on the hatching success and survival rate of these young crayfish during their first year of life (MOMOT and JONES, 1976) and that is a part of study on $A$. torrentium that need to be investigated in the future.

\section{ACKNOWLEDGEMENTS}

We are grateful to referees for all the comments and suggestions that have helped improving the manuscript.

\section{BIBLIOGRAPHY}

ABRAHAMSSON S.A.A., 1996. Dynamics of an isolated population of the crayfish Astacus astacus Linné. Oikos 17, 96-107.

ACKEFORS H.E.G., 1999. Observation on the yearly life cycle of Astacus astacus in a small lake in Sweden. Freshwater crayfish, 12, 413-429.

BREWIS J.M., BOWLER K., 1985. A study of reproductive females of the freshwater crayfish A. pallipes. Hydrobiologia, 121,145-149.

BROWN D., BOWLER K., 1977. A population study of the British freshwater crayfish Austropotamobius pallipes Lereboullet. Freshwater crayfish, 3, 33-50.

CARRAL J.M., CELADA J.D., GONZALEZ J., SAEZ-ROYUELA M., GAUDIOSO V.R., 1994. Mating and spawning of freshwater crayfish (Austropotamobius pallipes Lereboullet) under laboratory conditions. Aquaculture and fisheries Management, $25,721-727$.

CARRAL J.M., PÉREZ J.R., CELADA J.D., GONZALEZ J., SAEZ-ROYUELA M., MELENDRE P.M., AGUILER A., 2004. Egg production of the freshwater crayfish (Austropotamobius pallipes Lereboullet) under laboratory conditions: Relationship between egg number, egg diameter and female size. Program and Abstracts of 15th IAA Symposium. London, UK..

EVERSOLE A.G., MAZLUM Y., FONTENOT Q.C., TURKER H., 2002. Evaluation of a non-invasive technique for predicting reproductive success in white river crayfish. Freshwater crayfish, 13, 303-308.

GRANDJEAN F., ROMAIN D., AVILA-ZARZA C., BRAMARD M., SOUTY-GROSSET C., MOCQUARD J.P., 1997a. Morphometry, sexual dimorphism and size at maturity of the white-clawed crayfish Austropotamobius pallipes pallipes (Lereboullet) from a wild French population at Deux-Sèvres (Decapoda, Astacidae). Crustaceana 70 (1), 31-44.

GRANDJEAN F., ROMAIN D., SOUTY-GROSSET C., MOCQUARD J.P., 1997b. Size at sexual maturity and morphometric variability in three populations of Austropotamobius pallipes pallipes (Lereboullet, 1858) according to a restocking strategy. Crustaceana $70,454-468$.

HARLIOĞLU M.M., 1996. Comparative biology of the signal crayfish, Pacifastacus leniusculus (Dana), and the narrow-clawed crayfish, Astacus leptodactylus Eschscholtsz. Ph.D. Thesis, University of Nottingham, 435 p. 
HARLIOĞLU M.M., TÜRGÜLÜ I., 2000. The relationship between egg size and female size in freshwater crayfish, Astacus leptodactylus. Aquaculture International 8, 95-98.

HUNER J.V., LINDQVIST O.V., 1991. Special problems in freshwater crayfish egg production. In WENNER A., KURIS A. (eds.), Crustacean egg production, 235-246, A.A. Balkema, Roterdam.

KÖKSAL G., 1988. Astacus leptodactylus in Europe. In HOLDICH D.M., LOWERRY R.S. (eds.), Freshwater Crayfish: Biology, Management and Exploitation, 365-400, Croom Helm, London.

KULESH V., ALEKHNOVICH A., ABLOV S., 1999. Distribution and size structure of noble crayfish, Astacus astacus (L.), populations in Belarus. Freshwater Crayfish, 12, 835-845.

LAHTI E., LINDQVIST O.V. 1983. On the reproductive cycle of the crayfish Astacus astacus L. in Finland. Freshwater crayfish, 5, 18-26.

LAURENT P.J., 1988. Austropotamobius pallipes and A. torrentium, with observation on their interactions with other species in Europe. In HOLDICH D.M., LOWERY R.S. (eds.), Freshwater Crayfish: Biology, Management and Exploitation, 341-364, Croom Helm, London.

LOWERY R.S., 1988. Growth, moulting and reproduction. In HOLDICH D.M., LOWERY R.S. (eds.), Freshwater Crayfish: Biology, Management and Exploitation, 83-114, Croom Helm, London.

MACHINO Y., SKET B., TRONTELJ P., 2004. Phylogenetic relationship in the southern European crayfish Austropotamobius spp. based on mitochondrial $\mathrm{COI}$ gene sequences. IAA XV Book of Abstracts, 39, London.

MAGUIRE I., ERBEN R., KLOBUČAR G. I. V., LAJTNER, J., 2002. A year cycle of Austropotamobius torrentium (Schrank) in streams on Medvednica mountain (Croatia). Bull. Fr. Pêche Piscic., 367, 943-957.

MAGUIRE I., 2002. Porodica Astacidae u sjevero zapadnoj Hrvatskoj: 1-128. (PhD thesis, University of Zagreb). [In Croatian with English abstract.]

MAGUIRE I., GOTTSTEIN-MATOČEC S., 2004 The distribution pattern of freshwater crayfish in Croatia. Crustaceana 77 (1), 25-49.

MANKAMPA M., CHAISEMARTIN C., 1996. Étude comparative de cinq espèces d'écrevisses, définies par leurs populations naturelles du même secteur géographique. Vie milieu, 46 (1), 79-85.

MOMOT W.T., JONES P.D., 1976. The relationship between biomass, growth rate and annual production in the crayfish, Orconectes virilis. Freshwater crayfish, 3, 3-31.

MOMOT W.T., GOWING H., JONES P.D., 1978. The dynamics of crayfish and their role in the ecosystem. American Midland Naturalist, 99, 10-35.

MOMOT W. T., 1991. Potential for exploitation of freshwater crayfish in coolwater systems: management guidelines and issues. Fisheries, 16, 14-21.

MOMOT W. T., 1993. The role of exploitation in altering the processes regulation crayfish populations. Freshwater Crayfish, 11, 101-117.

NARODNE NOVINE, 30, 1994. Zakon o zaštiti prirode.

NARODNE NOVINE, 76, 1998. Pravilnik o zaštiti riječnih rakova

POLICAR T., 2004. PhD thesis completed. Crayfish news, 2, 24-25.

REYNOLDS J.D., 2002. Growth and reproduction. In HOLDICH D.M. (ed.), Biology of freshwater crayfish, 152-192, Blackwell science, Oxford. 
RHODES C.P., HOLDICH D.M., 1982. Observations on the fecundity of the freshwater crayfish Austropotamobius pallipes in the British Isles. Hydrobiologia, 89, 231-236

SCHELLENBERG A., 1928. Krebstiere oder Crustacea, 11 Decapoda, Zehnfüsser. Die Tierwelt Deutchlands 10, Gustav Fisher, Jena.

SKURDAL J., TAUGBØL T., 2002. Astacus. In HOLDICH D.M. (ed.), Biology of freshwater crayfish, 467-510, Blackwell science, Oxford.

STREISSL F., HÖDL W., 2002. Growth, morphometrics, size at maturity, sexual dimorphism and condition index of Austropotamobius torrentium Schrank. Hydrobiologia, 477, 201-208.

STUCKI T.P., 1999. Life cycle and life history of Astacus leptodactylus in Chatzensee Pond (Zürich) and lake Ägeri, Switzerland. Freshwater crayfish, 12, 430-448.

STUCKI T.P., 2002. Differences in life history of native and introduced crayfish species in Switzerland. Freshwater crayfish, 13, 463-476.

TAUGBØL T., SKURDAL J., FJELD E., 1988. Maturity and fecundity of Astacus astacus females in Norway. Freshwater crayfish, 7, 107-114.

TROSCHELJ P., SCHULZ U., BERG R., 1995. Seasonal activity of stone crayfish Austropotamobius torrentium. Freshwater Crayfish, 10, 196-199.

WOODLOCK B., REYNOLDS J.D., 1988. Laboratory breeding studies of freshwater crayfish Austropotamobius pallipes (Lereboullet). Freshwater biology, 19, 71-78. 
